\title{
The Choroid Plexus and Cerebrospinal Fluid: Emerging Roles in Development, Disease, and Therapy
}

\author{
Maria K. Lehtinen, ${ }^{1}$ Christopher S. Bjornsson, ${ }^{2}$ Susan M. Dymecki, ${ }^{3}$ Richard J. Gilbertson, ${ }^{4}$ David M. Holtzman, ${ }^{5}$ \\ and Edwin S. Monuki ${ }^{6}$ \\ ${ }^{1}$ Department of Pathology, Boston Children’s Hospital, Harvard Medical School, Boston, Massachusetts 02115, ${ }^{2}$ Neural Stem Cell Institute, Rensselaer, New \\ York 12144, ${ }^{3}$ Department of Genetics, Harvard Medical School, Boston, Massachusetts 02115, ${ }^{4}$ St. Jude Children's Research Hospital, Memphis, Tennessee \\ 03105, ${ }^{5}$ Department of Neurology, Washington University, St. Louis, Missouri 63110, and ${ }^{6}$ Department of Pathology and Laboratory Medicine, University \\ of California, Irvine School of Medicine, Irvine, California 92697
}

Although universally recognized as the source of cerebrospinal fluid (CSF), the choroid plexus (ChP) has been one of the most understudied tissues in neuroscience. The reasons for this are multiple and varied, including historical perceptions about passive and permissive roles for the $\mathrm{ChP}$, experimental issues, and lack of clinical salience. However, recent work on the ChP and instructive signals in the CSF have sparked new hypotheses about how the ChP and CSF provide unexpected means for regulating nervous system structure and function in health and disease, as well as new ChP-based therapeutic approaches using pluripotent stem cell technology. This minisymposium combines new and established investigators to capture some of the newfound excitement surrounding the ChP-CSF system.

\section{Introduction}

Almost 100 years ago to date, Harvey Cushing made the seminal discovery that the choroid plexus (ChP), a highly vascularized tissue located in each ventricle of the brain, secretes cerebrospinal fluid (CSF) (Cushing, 1914), casting aside lingering views of the $\mathrm{CSF}$ as a possible postmortem precipitate. In humans, the ChP produces $400-600 \mathrm{ml}$ of CSF each day, which is enough to turn over the CSF 3-4 times. The CSF then flows from the lateral ventricles to the third and fourth ventricles, and then into the subarachnoid space of the brain and spinal cord via openings (foramena) below the cerebellum (Fig. 1). The CSF returns to the peripheral circulation via resorption by arachnoid granulations in venous sinuses of the brain (Segal, 2005). The ChP-CSF therefore represents an independent circulatory system for the brain and spinal cord.

The ChP-CSF system is also unique in terms of how understudied it has been. A reflection of this comes from last year's

Received July 31, 2013; revised Sept. 13, 2013; accepted Sept. 17, 2013.

This work was supported by the following: Alfred P. Sloan Research Fellowship, Pediatric Hydrocephalus Foundation, Eleanor and Miles Shore Fellowship Program for Scholars in Medicine/Boston Children's Hospital Career Development Award, National Institutes of Health Grant R00 NS072192 to M.K.L., National Institutes of Health Grant R01 NH051936 to S.M.D., National Institutes of Health Grant R01-AG041861, Ellison Medical Foundation Grant AG-SS-2655-11 to Sally Temple, National Institutes of Health Grants 2R01CA129541, P01CA96832, P30CA021765, and DoD Synergy Grant Award CA093469 to R.J.G., National Institutes of Health Grants P50-AG05681, P01-AG03991, and P01-AG26276 to D.M.H., California Institute for Regenerative Medicine New Faculty Awards RN2-00915-1 and R01-NS064587, University of California, Irvine Institute for Clinical and Translational Science Pilot Project Award, and University of California, Irvine Alzheimer Disease Research Center Pilot Project Award to E.S.M. We thank Sally Temple for helpful suggestions on the manuscript. We apologize to investigators whose work we could not reference due to space limitations.

The authors declare no competing financial interests.

Correspondence should be addressed to either of the following: Dr. Maria K. Lehtinen, Department of Pathology, Boston Children's Hospital, Harvard Medical School, Boston, MA 02115,E-mail: maria.lehtinen@childrens.harvard.edu; or Edwin S. Monuki, Department of Pathology and Laboratory Medicine, University of California, Irvine School of Medicine, Irvine, CA 92697,E-mail:emonuki@uci.edu.

DOI:10.1523/JNEUROSCI.3258-13.2013

Copyright $\odot 2013$ the authors $\quad 0270-6474 / 13 / 3317553-07 \$ 15.00 / 0$
Society for Neuroscience meeting: of the 17,255 searchable abstracts, only 9 had "choroid plexus" in the title or as a keyword. Why is that? Part of the answer may relate to the generally perceived "uninteresting" functions historically attributed to the CSF, such as providing buoyancy and acting as a passive sink for waste. The ChP has also had limited salience in the clinical arena. $\mathrm{ChP}$ pathology in most neurological or psychiatric conditions is nonspecific (atrophy or accelerated atrophy), and apart from uncommon types of hydrocephalus, the ChP is not known to be responsible for primary symptoms or particularly helpful for differential diagnosis. There have also been experimental barriers, including a relative lack of $\mathrm{ChP}$-selective tools, difficulties obtaining CSF from small animal models, and challenges inherent in studying a fluid rather than a tissue.

Recent advances, however, have begun to transform our view of the ChP-CSF system. Newer techniques indicate that CSF is a rich source of proteins, lipids, hormones, cholesterol, glucose, microRNAs, and many other molecules and metabolites that influence a multitude of CNS functions, including neurogenesis in embryos and adults (Dziegielewska et al., 1981; Zappaterra et al., 2007; Lehtinen and Walsh, 2011; Zappaterra and Lehtinen, 2012; Burgos et al., 2013). Spurred by the clinical utility of CSF biomarkers for Alzheimer's disease, there is tremendous interest in CSF biomarker discovery for the diagnosis and management of CNS disorders, and the ability to derive secretory ChP cells from embryonic stem cells sets the stage for unique ChP-based strategies for treating a host of CNS diseases. In this minireview, we highlight some of the new roles and emerging principles for the ChP-CSF system in the areas of development, disease, and therapy.

\section{Choroid plexus development}

Only recently have investigators begun to use modern techniques to study development of the ChP itself. The ChP forms at and 


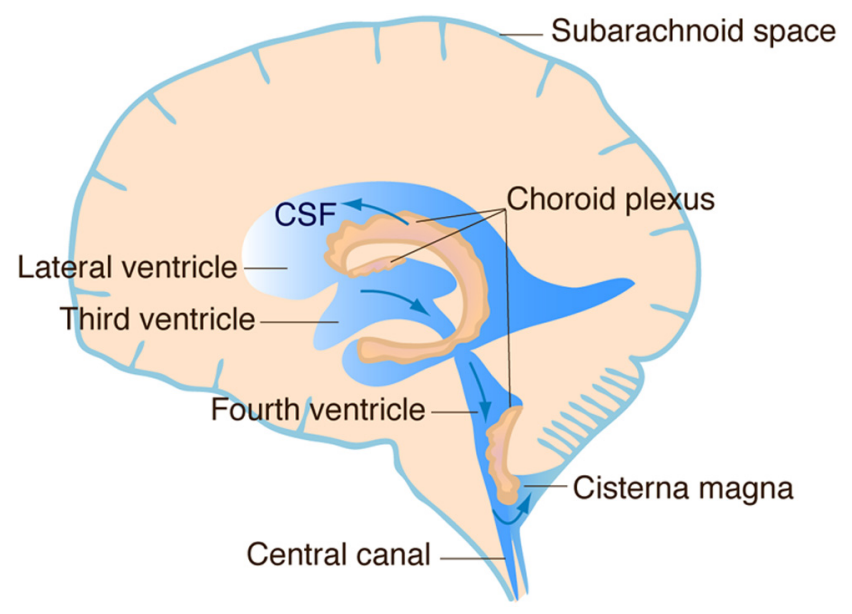

Figure 1. CSF secretion and flow. The CSF is secreted by the choroid plexus, a tissue located in each ventricle in the brain. CSF flows from the lateral ventricles to the third and fourth ventricles, then into the subarachnoid space of the brain and spinal cord via openings (foramena) below the cerebellum. CSF is then resorbed into the peripheral circulation by arachnoid granulations in venous sinuses of the brain.

adjacent to the embryonic dorsal midline in the hindbrain, diencephalon, and telencephalon. Whereas ChP stroma has mesenchymal origins, including meningeal cells, $\mathrm{ChP}$ epithelial cells (CPECs) are derived from neuroepithelium, and important aspects of CPEC specification are now understood. Genetic lineage analyses indicate that $\mathrm{CPECs}$ originate from the roof plate (Awatramani et al., 2003; Currle et al., 2005; Hunter and Dymecki, 2007), a well-known signaling center in early CNS development. Roof plate cells differentiate directly into CPECs at all four ChP sites, although in the telencephalon, most CPECs are induced indirectly by the roof plate (Bailey, 1915; Currle et al., 2005), and multiple studies implicate bone morphogenetic proteins as the instructive roof plate-derived molecules for CPEC fate (Hebert et al., 2002; Cheng et al., 2006; Fernandes et al., 2007; Watanabe et al., 2012). CPEC differentiation is evident before definitive neurogenesis or ependymal differentiation ensues, and in vivo and in vitro mouse studies indicate that CPEC competency is restricted to early-stage neuroepithelial cells in the telencephalon and roof plate regions (Thomas and Dziadek, 1993; Watanabe et al., 2012).

Other studies have begun to clarify the epithelial-mesenchmymal interactions involved in ChP development. Recent genetic experiments in the mouse embryo (Huang et al., 2009; Nielsen and Dymecki, 2010) reveal a central role for the secreted morphogen Sonic Hedgehog (Shh) in coordinating the developmental challenge of matching CPEC numbers to vasculature. The critical source of Shh was found to be embryonic CPECs (Bitgood and McMahon, 1995; Huang et al., 2009; Nielsen and Dymecki, 2010) (Fig. 2). The responding cell populations were found to be the perivascular cells (pericytes) in the underlying $\mathrm{ChP}$ vascular bed (Nielsen and Dymecki, 2010), and the progenitor cells for the ChPe located laterally (Huang et al., 2009). CPECs are postmitotic, expanding through cell addition supplied by progenitor cells residing in the lateral periphery of the hindbrain ChP, in a territory situated in neuroectoderm and demarcated molecularly by expression of the transcription factor Lmxla and the secreted signaling molecule Gdf7 (Currle et al., 2005; Landsberg et al., 2005; Hunter and Dymecki, 2007; Chizhikov et al., 2010). Thus, although Shh is present in CSF, here it acts on cell populations constituent to, even internal to, the ChP, suggesting Shh release across the basal surface of the epithelium to deeper mesenchymal cells like pericytes, as opposed to only apical release into the CSF.
Shh, acting on these two cell populations (pericytes and CPEC progenitor cells), was found to regulate at least two key processes: outgrowth of vasculature in the ChP and enhanced CPEC generation from their neurectodermal progenitor pool to ensheath that expanding vasculature. In the absence of CPEC-produced Shh, a severely hypoplastic structure develops, deficient in CPEC and vasculature, as well as showing reduced folding of the ChP surface (Huang et al., 2009; Nielsen and Dymecki, 2010). Shh thus appears to orchestrate the codevelopment of two disparate cell lineages during $\mathrm{ChP}$ morphogenesis: underlying perivascular cells and more distant CPEC progenitor cells. The relative contribution of each of these Hh-responsive populations to overall $\mathrm{ChP}$ development remains to be delineated and is an area of active investigation. For example, it seems straightforward that pericyte action in response to Shh likely enables vascular expansion and outgrowth, but pericytes may also serve, via factor secretion, to boost CPEC production from the neuroectodermal progenitor pool. Answers to these possibilities await additional manipulations of Shh pathway genes, restricted to pericytes versus CPEC progenitors.

\section{CSF and distribution of instructive cues in development}

Beyond development of the ChP itself, recent studies have begun to delineate how the embryonic $\mathrm{ChP}$ regulates development of the rest of the brain. The earliest born neural stem cells in the developing cerebral cortex are located along CSF-filled ventricles (Fig. 3A). A number of genes that directly regulate cortical progenitor cell proliferation and migration have been identified, and most of these genes are expressed by cortical progenitor cells (Thornton and Woods, 2009; Manzini and Walsh, 2011). The large literature on brain development also demonstrates critical roles that extrinsic cues, including growth factors and morphogens (e.g., Fgf, Bmps, Shh, Wnt, and RA), have on cortical progenitor cells (for review, see Lehtinen and Walsh, 2011; Tiberi et al., 2012). Yet the evidence from the majority of these studies has never fully explained how these signals access cortical progenitors at the ventricular surface, where the primary access to signals is likely via the CSF. Recent studies have begun to probe this question and, indeed, have demonstrated that secreted signals emanating from the CSF provide growth-promoting signals to neural stem cells (Lehtinen et al., 2011).

Embryonic CSF, without any additional exogenous growthpromoting signals, can promote the development and growth of neural stem cells and cortical explants, and the favorable effects of CSF are age-dependent (Lehtinen et al., 2011). For example, young stem cells bathed in embryonic CSF divide robustly. By contrast, the same stem cells bathed in CSF obtained at other ages, including adult CSF, display only limited cell division. These results agree with findings that many protein signals in the CSF fluctuate with age. For instance, CSF-insulin-like growth factor-2 (IGF2) levels, attributed largely to ChP secretion, peak during brain development. CSF-IGF2 stimulates cell division by binding to receptors on the surface of neural stem cells (Lehtinen et al., 2011). Intracerebroventricular injections of IGF1, IGF1neutralizing antibodies, and IGF1R inhibitors further demonstrate that IGF signals delivered by the embryonic CSF stimulate proliferative events in the cortical ventricular zone (MairetCoello et al., 2009). Finally, mouse genetic approaches have further shown that IGF2 regulates neurogenesis, formation of the uppermost layers of the cerebral cortex, and brain size (Lehtinen et al., 2011).

Intriguingly, when neural stem cells lose their distinct polarity, including genetic manipulation of the polarity gene Pals1 


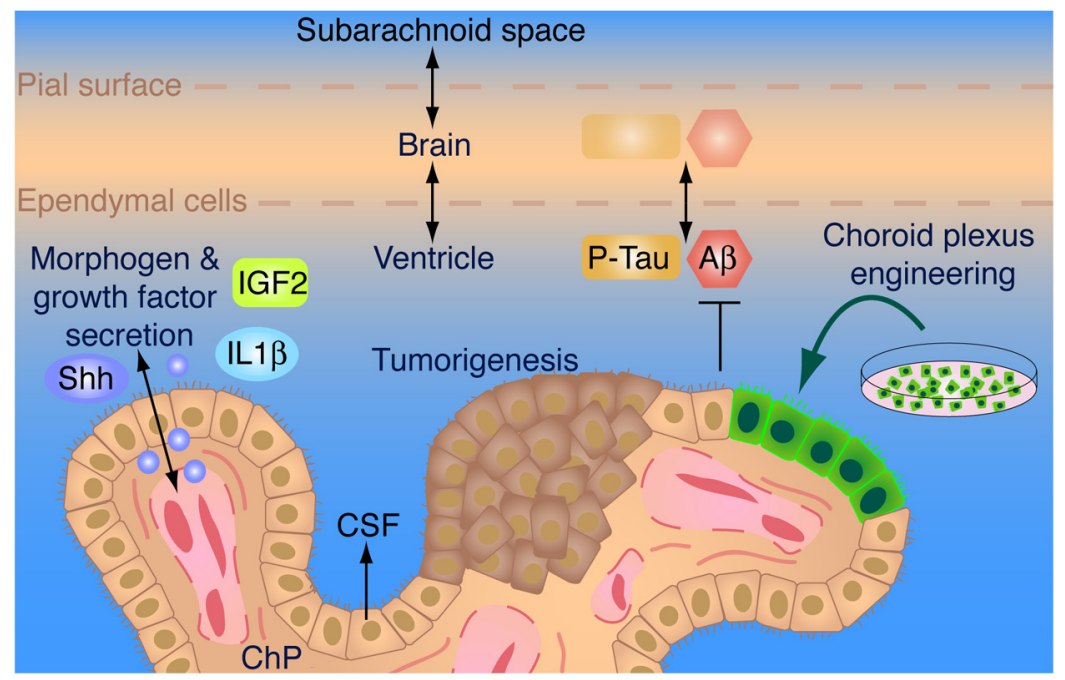

Figure 2. Overview of ChP-CSF- brain interactions. In addition to secreting CSF, ChP epithelial cells secrete morphogens and proteins with sites of action within the $\mathrm{ChP}$ (e.g., Shh on vasculature and $\mathrm{ChP}$ progenitor cells) and beyond the $\mathrm{ChP}$ on neural stem cells (e.g., IGF2 on cerebral cortical progenitor cells, and cytokines on adult neural stem cells). The ChP can be the site of tumorigenesis (brown). It also plays a role in protecting the brain from $A \beta$ toxicity. Because there is an exchange between the brain's interstitial fluid and CSF (perforated line), the ratio of phosphorylated Tau:A $\beta$ provides an early diagnostic for Alzheimer's disease and can predict the severity of neurodegenerative decline. Recent advances have made possible the engineering and production of ES-derived ChP epithelial cells (green).

(Kim et al., 2010; Lehtinen et al., 2011) or the ciliary gene Arl13b (Higginbotham et al., 2013), they share a striking deficiency in IGF signaling receptors and decreased IGF signaling pathway activation on the apical surface of neural stem cells. Recent evidence indicates that IGF1 binding to the IGF1R on primary cilia of radial glial progenitor cells accelerates $\mathrm{G}_{1}-\mathrm{S}$ progression and ciliary resorption by a noncanonical $\mathrm{G} \beta \gamma$ signaling pathway (Yeh et al., 2013). Thus, the intrinsic regulation of apical morphology as well as ciliogenesis may be crucial for the capacity of apical progenitors to access and respond to CSF-distributed signals. Impaired primary cilia are associated with a number of central nervous system disorders. These findings also resonate with observations from the development of other organs, where mutations at the primary cilium can lead to a wide range of physiological disruptions ranging from the mirroring of internal organs in situs inversus, to polycystic kidney disease (for review, see Louvi and Grove, 2011).

Primary cilia are known to relay several additional extrinsic signals to cell bodies, including Shh (Huangfu et al., 2003), Fgfs (Neugebauer et al., 2009), and Wnt (Gerdes et al., 2007; for review, see Eggenschwiler and Anderson, 2007). Together with observations that active signaling pathway components are enriched at the apical, ventricular surface, for instance, phosphotyrosine (Chenn et al., 1998), phospho-AKT (Poduri et al., 2012), and phospho-MAPK (Toyoda et al., 2010), these findings have sparked investigations into which additional instructive cues are received by progenitor cells from the CSF. To this end, advances in proteomic tools, including mass spectrometry, have allowed for an improved characterization of the CSF proteome. We now know that, in addition to secreted growth factors and morphogens, the CSF is home to cytokines, extracellular matrix proteins, binding proteins, adhesion molecules, and many others factors whose availabilities and activities are tightly regulated by the ChP-CSF system (Parada et al., 2005; Redzic et al., 2005; Martín et al., 2006; Zappaterra et al., 2007; Huang et al., 2010; Lehtinen and Walsh, 2011). Overall, these studies have demonstrated that, rather than being merely a fluid cushion for the brain with vari- ous proteins passively oozing into and out of the CSF, the embryonic ChP-CSF system actively distributes secreted signals to developing progenitor cells, instructing cerebral cortical development.

\section{CSF and instructive cues for adult neurogenesis}

ChP-CSF regulation of neural progenitors has now been implicated not only in embryos, but also in adults. Neurogenesis persists into adulthood in select brain regions in most mammals, namely, the subgranular zone of the dentate gyrus and the subventricular zone (SVZ) of the lateral ventricles (Temple and Alvarez-Buylla, 1999). Within the SVZ, neural progenitor cells (NPCs), which include neural stem cells and other types of progenitor cells, give rise to neuroblasts that migrate to produce olfactory bulb interneurons throughout life (Doetsch et al., 1997). Intrinsic and extrinsic cues within the SVZ stem cell niche govern NPC self-renewal and differentiation (Doetsch, 2003). For example, several key morphogens that influence neurogenesis in the adult SVZ are known to be synthesized by the ChP, including EGF (Tropepe et al., 1997; Enwere et al., 2004), FGF-2 (Redzic et al., 2005), and retinoic acid (Haskell and LaMantia, 2005). A subpopulation of SVZ NPCs is situated to receive signals from the CSF via apical processes that span the ependymal layer and project into the ventricular space (Mirzadeh et al., 2008; Shen et al., 2008). In the mouse, these projections are enriched in the signaling/adhesion receptor VCAM1, which is important for maintaining niche architecture and NPC lineage progression, and is sensitive to changes in environmental cytokines, such as IL-1 $\beta$ produced by the ChP (Kokovay et al., 2012). The immediate proximity of the ChP to the SVZ has led to increasing interest in defining in-depth the role of this tissue in adult neurogenesis (Falcao et al., 2012).

With aging, neurogenesis declines, leading to fewer new olfactory bulb interneurons and deficits in fine olfactory discrimination (Tropepe et al., 1997; Enwere et al., 2004). SVZ architecture is disrupted (Shook et al., 2012), and the number of SVZ NPCs dwindles. The ChP also undergoes dramatic changes during the course of aging. Morphological changes in the ChP epithelium mirror declining fluid transport and protein synthesis (Redzic et al., 2005; Chen et al., 2012), including reduced production of growth factors that are known to impact neurogenesis (Emerich et al., 2007). Addition of growth factors secreted by the ChP, including EGF (Tropepe et al., 1997; Enwere et al., 2004) and FGF-2 (Redzic et al., 2005), can partially revitalize neurogenesis in aged mice.

Current research is investigating the influence of extrinsic cues on SVZ structure and function throughout adulthood, and in particular in how ChP-derived factors impact and contribute to age-related changes in niche architecture and neurogenic output. Long-term time-lapse imaging of ChP explants cocultured with isolated, single SVZ NPCs enables the visualization of ChP impact on NPC clonal development, and the analysis of heterochronic combinations of young ChP with aged SVZ and vice versa. Single-cell, clonal time-lapse analysis also yields detailed information on cell behavior, survival, differentiation, and divi- 
sion rate. Initial in vitro $2-\mathrm{D}$ coculture studies demonstrate that cell behavior and clonal output are stimulated in the presence of ChP tissue in both young and aged SVZ cells, with preservation of the NPC state and inhibition of differentiation. Efforts to identify the factors responsible for regulating neurogenesis through $\mathrm{ChP}$ conditioned media analysis and transcriptome studies are currently underway.

\section{Choroid plexus tumors}

As with virtually all tissues of the body, the ChP can be a target for cancer as well. CPECs are the presumed cells of origin for most ChP tumors, although rare intraventricular meningiomas are thought to arise from neoplastic meningeal cells in $\mathrm{ChP}$ stroma. Although tumors of the ChP are rare in children and adults, accounting for $<2 \%$ of all pediatric brain tumors (CBTRUS, 2006; Paulus and Brandner, 2007), they are most commonly observed in infants (accounting for 10-20\% of brain tumors in infants in their first year; median age of diagnosis, 3.5 years) (Safaee et al., 2013) (Fig. 2). Efforts to assemble the critical mass of patients and experts necessary to advance cures of the disease have proved relatively unsuccessful, and treatment options and survival rates remain limited (Wolff et al., 2002; LafayCousin and Strother, 2009). Recent developments have innovated a cross-species genomics approach that allows mapping of the cells of origin of childhood brain tumors. Targeting these cells in mice with appropriate mutations identified in the human disease results in brain tumor models that recapitulate human tumors (Gibson et al., 2010; Johnson et al., 2010; Gilbertson, 2011). This approach allows for the application of these model systems in high-throughput drug screens of new treatments that can be rapidly translated to the clinic (Atkinson et al., 2011).

The R.J.G. laboratory has adapted this same approach to increase understanding of the biology and treatment of pediatric choroid plexus carcinoma (CPC). In a collaboration involving experts in brain tumor biology, neurobiology, genomics, neuropathology, and drug development, they have used in utero electroporation to develop a new and highly flexible model of CPC. Comprehensive histologic and genomic analyses of these tumors have validated these mouse tumors as faithful models of human CPC and enabled the identification of nonrandom large chromosomal and focal alterations that are secondary events in the development of CPCs. Further in utero electroporation studies of these aberrantly altered genes have identified those that alter normal ChP development and might therefore impact CPC formation. Finally, cells from this CPC model have been adapted for high-throughput drug screens. To date, mouse models have been screened against $>1.2$ million compounds, identifying numerous highly active novel agents for further preclinical testing, which we hope will improve the survival of children with CPC.

\section{CSF in Alzheimer's disease}

Recent studies suggest that the ChP-CSF system plays central roles in Alzheimer's disease (AD), the most common cause of dementia. It is estimated that there are $\sim 30$ million cases of $\mathrm{AD}$ worldwide, and this number will triple in the next 40 years unless a disease-modifying therapy is developed (Holtzman et al., 2011). An important series of findings over the last 25 years in both the rare forms of early-onset, dominantly inherited $\mathrm{AD}(<1 \%$ of $\mathrm{AD})$ as well as in the common late-onset $\mathrm{AD}$ (age of onset $>60,>99 \%$ of $\mathrm{AD}$ ) is that the pathology underlying the disease begins to develop $\sim 15$ years before the onset of cognitive decline. By the time that cognitive decline is present, there is not only substantial amyloid- $\beta(\mathrm{A} \beta)$ deposition in the form of amyloid plaques, there is also tau aggregation in the form of neurofibrillary tangles, neuroinflammation, and neuronal and synaptic loss in certain brain regions (Fagan et al., 2009; Perrin et al., 2009). Thus, although our understanding of the pathogenesis of $\mathrm{AD}$ has greatly increased, if we are to develop effective treatments that can delay the onset or slow $\mathrm{AD}$, it will be critical to accurately diagnose 
$\mathrm{AD}$ both in its early clinical stages as well as before the onset of cognitive decline (preclinical AD).

Dynamic and static assessments of several CSF proteins have proven to be very useful in detecting different aspects of $\mathrm{AD}$ pathology as well as in identifying fundamental aspects of protein metabolism relevant to $\mathrm{AD}$. CSF levels of $\mathrm{A} \beta 42$ decrease with the onset of $\mathrm{A} \beta$ deposition in the brain beginning $\sim 10-15$ years before the onset of cognitive decline. This is the result of an equilibrium between soluble monomeric $\mathrm{A} \beta 42$ in CSF, brain interstitial fluid, and amyloid plaques (Fig. 2). CSF tau and phosphorylated forms of tau increase in CSF $\sim 5-10$ years before cognitive decline, probably because of an increase in tau release from neurons related in some way to neurodegeneration. The combination of these changes can predict the rate of decline in individuals who have mild cognitive impairment/very mild dementia resulting from $\mathrm{AD}$, as well as the conversion from cognitive normality to dementia over a 5 -year period. In addition to tau, another marker of neurodegeneration in CSF is the neuronal protein VILIP-1 (Tarawneh et al., 2011), which has similar diagnostic and prognostic value to tau in $\mathrm{AD}$. In addition to static measurement of these proteins in CSF, using metabolic labeling with ${ }^{13} \mathrm{C}$-labeled amino acids, the synthesis and clearance rate of $\mathrm{A} \beta$ are extremely rapid in the CNS/CSF (on the order of hours) (Bateman et al., 2006). Interestingly, the clearance rate of $\mathrm{A} \beta$ appears to be slower in individuals with $\mathrm{AD}$ compared with agematched controls, suggesting that slowed $\mathrm{A} \beta$ clearance may be central in causing late-onset $\mathrm{AD}$. In dominantly inherited earlyonset $\mathrm{AD}$, the production rate of $\mathrm{A} \beta 42$ relative to $\mathrm{A} \beta 40$ is elevated in many individuals as predicted (Potter et al., 2013). However, the turnover rate of CSF A $\beta 42$ is faster in these individuals if they already have amyloid plaques, suggesting active deposition of soluble A $\beta 42$ into plaques. Together, these findings suggest that the kinetics of biomarker availability in the CSF serve as a harbinger of cognitive fitness, opening avenues toward the possibility of harnessing the CSF for tailoring personalized therapeutic approaches for detecting, diagnosing, and treating $\mathrm{AD}$ in the aging brain.

\section{Choroid plexus in therapy}

Despite the many recent advances in medicine, effective therapies for most CNS diseases remain few and far between. The reasons for this are many but include the complexities of the human CNS itself and the many difficulties in getting therapeutic compounds past CNS barriers, particularly the blood-brain barrier (BBB). Because there is no CSF-brain barrier (Goldmann, 1913), CNS delivery past these barriers can be achieved clinically by direct injections into the CSF (intrathecal or intraventricular) (e.g., Dickson et al., 2007). However, such injections come with multiple downsides, such as the many repeated treatments needed over a lifetime and associated safety issues. Cell-based therapies that are long-lived, safe, and provide long-term delivery to the CSF would circumvent these issues and could represent ideal therapeutic strategies for treating many CNS diseases. The promise of ChP-based therapies has been shown using transplanted primary choroid plexus (e.g., encapsulated porcine ChP) (Thanos et al., 2010) and ChP-tropic AAV viruses (Haskell et al., 2003), although these approaches also have inherent limitations (e.g., Manno et al., 2006).

A stem cell-based approach for generating CPECs (patent pending) (Watanabe et al., 2012) that could address many of these limitations was recently described. CPECs are the workhorse cells that perform the major secretory, transport, detoxification, and barrier functions of the ChP. CPECs are born to secrete CSF, normally producing 400-600 $\mathrm{ml}$ (approximately 2 cups) of CSF every day in humans, which is continuous with brain interstitial fluid across ependymal, pial, and certain perivascular surfaces (Serot et al., 2000; Emerich et al., 2005) (Fig. 2). In vivo, CPECs are long-lived, exhibiting little proliferation or turnover; accordingly, primary CPECs have been difficult to expand in culture to a significant degree (Watanabe et al., 2012). Using ES cells as starting material (which circumvents the expandability problem), the production of derived CPECs (dCPECs) follows important developmental principles, such as the ability of BMP4 to act as an instructive morphogen for CPEC fate (Cheng et al., 2006; Hu et al., 2008) and the restriction of CPEC potential to early-stage neuroepithelial cells rather than later-stage radial glia (Thomas and Dziadek, 1993). Importantly, both primary and dCPECs can integrate readily into host $\mathrm{ChP}$ after intraventricular injection (Watanabe et al., 2012), which represents an attractive and clinically feasible approach for dCPEC-based therapies (Fig. 2). Given that multiple highly expressed CPEC gene loci have been identified (e.g., the TRANSTHYRETIN gene), genetic engineering approaches to produce high levels of therapeutic proteins or peptides for natural, safe, and long-term delivery into the CNS should now be feasible. The ability to generate and engineer dCPECs could represent transformative approaches for treating a wide range of CNS diseases. In addition, given the lack of significant barriers between the bloodstream and the ChP itself, dCPECs provide a new, clinically feasible target for drug screens and therapeutic strategies that can bypass the BBB (Gonzalez et al., 2012).

In conclusion, the ChP-CSF system actively coordinates the development and health of the nervous system throughout life. The growing body of work on the ChP-CSF system summarized in this minireview marks the beginning of a new era for studies of this system. Understanding the constituency of the CSF and the actions of the ChP-CSF system is important not only for guiding basic biology and stem cell research but also for propelling current and potential uses in pharmacologic and surgical therapies for hydrocephalus, cancer, neurodegenerative disease, and beyond. Because the ChP-CSF system interacts with essentially every other system in the CNS, we hope this "state of the field address" provides inspiration for advancing past outdated conceptual and technical barriers in the field, sparking initiatives that will harness what the ChP-CSF system has to offer in service of nervous system repair.

\section{References}

Atkinson JM, Shelat AA, Carcaboso AM, Kranenburg TA, Arnold LA, Boulos N, Wright K, Johnson RA, Poppleton H, Mohankumar KM, Féau C, Phoenix T, Gibson P, Zhu L, Tong Y, Eden C, Ellison DW, Priebe W, Koul D, Yung WK, et al. (2011) An integrated in vitro and in vivo highthroughput screen identifies treatment leads for ependymoma. Cancer Cell 20:384-399. CrossRef Medline

Awatramani R, Soriano P, Rodriguez C, Mai JJ, Dymecki SM (2003) Cryptic boundaries in roof plate and choroid plexus identified by intersectional gene activation. Nat Genet 35:70-75. CrossRef Medline

Bailey P (1915) Morphology of the roof plate of the forebrain and the lateral choroid plexuses in the human embryo. J Comp Neurol 26:79-120.

Bateman RJ, Munsell LY, Morris JC, Swarm R, Yarasheski KE, Holtzman DM (2006) Human amyloid-beta synthesis and clearance rates as measured in cerebrospinal fluid in vivo. Nat Med 12:856-861. CrossRef Medline

Bitgood MJ, McMahon AP (1995) Hedgehog and Bmp genes are coexpressed at many diverse sites of cell-cell interaction in the mouse embryo. Dev Biol 172:126-138. CrossRef Medline

Burgos KL, Javaherian A, Bomprezzi R, Ghaffari L, Rhodes S, Courtright A, Tembe W, Kim S, Metpally R, Van Keuren-Jensen K (2013) Identification of extracellular miRNA in human cerebrospinal fluid by nextgeneration sequencing. Rna 19:712-722. CrossRef Medline 
CBTRUS (2006) Statistical report: primary brain tumors in the United States, 1995-1999. Hinsdale, IL: CBTRUS.

Chen CP, Chen RL, Preston JE (2012) The influence of ageing in the cerebrospinal fluid concentrations of proteins that are derived from the choroid plexus, brain, and plasma. Exp Gerontol 47:323-328. CrossRef Medline

Cheng X, Hsu CM, Currle DS, Hu JS, Barkovich AJ, Monuki ES (2006) Central roles of the roof plate in telencephalic development and holoprosencephaly. J Neurosci 26:7640-7649. CrossRef Medline

Chenn A, Zhang YA, Chang BT, McConnell SK (1998) Intrinsic polarity of mammalian neuroepithelial cells. Mol Cell Neurosci 11:183-193. CrossRef Medline

Chizhikov VV, Lindgren AG, Mishima Y, Roberts RW, Aldinger KA, Miesegaes GR, Currle DS, Monuki ES, Millen KJ (2010) Lmxla regulates fates and location of cells originating from the cerebellar rhombic lip and telencephalic cortical hem. Proc Natl Acad Sci U S A 107:10725-10730. CrossRef Medline

Currle DS, Cheng X, Hsu CM, Monuki ES (2005) Direct and indirect roles of CNS dorsal midline cells in choroid plexus epithelia formation. Development 132:3549-3559. CrossRef Medline

Cushing H (1914) Studies on the cerebro-spinal fluid. J Med Res 31:1-19. Medline

Dickson P, McEntee M, Vogler C, Le S, Levy B, Peinovich M, Hanson S, Passage M, Kakkis E (2007) Intrathecal enzyme replacement therapy: successful treatment of brain disease via the cerebrospinal fluid. Mol Genet Metab 91:61-68. CrossRef Medline

Doetsch F (2003) A niche for adult neural stem cells. Curr Opin Genet Dev 13:543-550. CrossRef Medline

Doetsch F, García-Verdugo JM, Alvarez-Buylla A (1997) Cellular composition and three-dimensional organization of the subventricular germinal zone in the adult mammalian brain. J Neurosci 17:5046-5061. Medline

Dziegielewska KM, Evans CA, Lai PC, Lorscheider FL, Malinowska DH, Møllgård K, Saunders NR (1981) Proteins in cerebrospinal fluid and plasma of fetal rats during development. Dev Biol 83:193-200. CrossRef Medline

Eggenschwiler JT, Anderson KV (2007) Cilia and developmental signaling. Annu Rev Cell Dev Biol 23:345-373. CrossRef Medline

Emerich DF, Skinner SJ, Borlongan CV, Vasconcellos AV, Thanos CG (2005) The choroid plexus in the rise, fall and repair of the brain. Bioessays 27:262-274. CrossRef Medline

Emerich DF, Schneider P, Bintz B, Hudak J, Thanos CG (2007) Aging reduces the neuroprotective capacity, VEGF secretion, and metabolic activity of rat choroid plexus epithelial cells. Cell Transplant 16:697-705. Medline

Enwere E, Shingo T, Gregg C, Fujikawa H, Ohta S, Weiss S (2004) Aging results in reduced epidermal growth factor receptor signaling, diminished olfactory neurogenesis, and deficits in fine olfactory discrimination. J Neurosci 24:8354-8365. CrossRef Medline

Fagan AM, Mintun MA, Shah AR, Aldea P, Roe CM, Mach RH, Marcus D, Morris JC, Holtzman DM (2009) Cerebrospinal fluid tau and ptau(181) increase with cortical amyloid deposition in cognitively normal individuals: implications for future clinical trials of Alzheimer's disease. EMBO Mol Med 1:371-380. CrossRef Medline

Falcao AM, Marques F, Novais A, Sousa N, Palha JA, Sousa JC (2012) The path from the choroid plexus to the subventricular zone: go with the flow! Front Cell Neurosci 6:34. CrossRef Medline

Fernandes M, Gutin G, Alcorn H, McConnell SK, Hébert JM (2007) Mutations in the BMP pathway in mice support the existence of two molecular classes of holoprosencephaly. Development 134:3789-3794. CrossRef Medline

Gerdes JM, Liu Y, Zaghloul NA, Leitch CC, Lawson SS, Kato M, Beachy PA, Beales PL, DeMartino GN, Fisher S, Badano JL, Katsanis N (2007) Disruption of the basal body compromises proteasomal function and perturbs intracellular Wnt response. Nat Genet 39:1350-1360. CrossRef Medline

Gibson P, Tong Y, Robinson G, Thompson MC, Currle DS, Eden C, Kranenburg TA, Hogg T, Poppleton H, Martin J, Finkelstein D, Pounds S, Weiss A, Patay Z, Scoggins M, Ogg R, Pei Y, Yang ZJ, Brun S, Lee Y, et al. (2010) Subtypes of medulloblastoma have distinct developmental origins. Nature 468:1095-1099. CrossRef Medline

Gilbertson RJ (2011) Mapping cancer origins. Cell 145:25-29. CrossRef Medline
Goldmann EE (1913) Vitalfarbung am Zentral-nervensystem: Abh Preuss Akad Wissensch, Physkol Mathem Klass.

Gonzalez AM, Leadbeater WE, Burg M, Sims K, Terasaki T, Johanson CE, Stopa EG, Eliceiri BP, Baird A (2012) Targeting choroid plexus epithelia and ventricular ependyma for drug delivery to the central nervous system. BMC Neurosci 12:4. CrossRef Medline

Haskell GT, LaMantia AS (2005) Retinoic acid signaling identifies a distinct precursor population in the developing and adult forebrain. J Neurosci 25:7636-7647. CrossRef Medline

Haskell RE, Hughes SM, Chiorini JA, Alisky JM, Davidson BL (2003) Viralmediated delivery of the late-infantile neuronal ceroid lipofuscinosis gene, TPP-I to the mouse central nervous system. Gene Ther 10:34-42. CrossRef Medline

Hébert JM, Mishina Y, McConnell SK (2002) BMP signaling is required locally to pattern the dorsal telencephalic midline. Neuron 35:1029-1041. CrossRef Medline

Higginbotham H, Guo J, Yokota Y, Umberger NL, Su CY, Li J, Verma N, Hirt J, Ghukasyan V, Caspary T, Anton ES (2013) Arl13b-regulated cilia activities are essential for polarized radial glial scaffold formation. Nat Neurosci 16:1000-1007. CrossRef Medline

Holtzman DM, Morris JC, Goate AM (2011) Alzheimer's disease: the challenge of the second century. Sci Transl Med 3:77sr71. CrossRef Medline

Hu JS, Doan LT, Currle DS, Paff M, Rheem JY, Schreyer R, Robert B, Monuki ES (2008) Border formation in a Bmp gradient reduced to single dissociated cells. Proc Natl Acad Sci U S A 105:3398-3403. CrossRef Medline

Huang X, Ketova T, Fleming JT, Wang H, Dey SK, Litingtung Y, Chiang C (2009) Sonic hedgehog signaling regulates a novel epithelial progenitor domain of the hindbrain choroid plexus. Development 136:2535-2543. CrossRef Medline

Huang X, Liu J, Ketova T, Fleming JT, Grover VK, Cooper MK, Litingtung Y, Chiang C (2010) Transventricular delivery of Sonic hedgehog is essential to cerebellar ventricular zone development. Proc Natl Acad Sci U S A 107:8422-8427. CrossRef Medline

Huangfu D, Liu A, Rakeman AS, Murcia NS, Niswander L, Anderson KV (2003) Hedgehog signalling in the mouse requires intraflagellar transport proteins. Nature 426:83-87. CrossRef Medline

Hunter NL, Dymecki SM (2007) Molecularly and temporally separable lineages form the hindbrain roof plate and contribute differentially to the choroid plexus. Development 134:3449-3460. CrossRef Medline

Johnson RA, Wright KD, Poppleton H, Mohankumar KM, Finkelstein D, Pounds SB, Rand V, Leary SE, White E, Eden C, Hogg T, Northcott P, Mack S, Neale G, Wang YD, Coyle B, Atkinson J, DeWire M, Kranenburg TA, Gillespie Y, et al. (2010) Cross-species genomics matches driver mutations and cell compartments to model ependymoma. Nature 466: 632-636. CrossRef Medline

Kim S, Lehtinen MK, Sessa A, Zappaterra MW, Cho SH, Gonzalez D, Boggan B, Austin CA, Wijnholds J, Gambello MJ, Malicki J, LaMantia AS, Broccoli V, Walsh CA (2010) The apical complex couples cell fate and cell survival to cerebral cortical development. Neuron 66:69-84. CrossRef Medline

Kokovay E, Wang Y, Kusek G, Wurster R, Lederman P, Lowry N, Shen Q, Temple S (2012) VCAM1 is essential to maintain the structure of the SVZ niche and acts as an environmental sensor to regulate SVZ lineage progression. Cell Stem Cell 11:220-230. CrossRef Medline

Lafay-Cousin L, Strother D (2009) Current treatment approaches for infants with malignant central nervous system tumors. Oncologist 14:433444. CrossRef Medline

Landsberg RL, Awatramani RB, Hunter NL, Farago AF, DiPietrantonio HJ, Rodriguez CI, Dymecki SM (2005) Hindbrain rhombic lip is comprised of discrete progenitor cell populations allocated by Pax6. Neuron 48:933947. CrossRef Medline

Lehtinen MK, Walsh CA (2011) Neurogenesis at the brain-cerebrospinal fluid interface. Annu Rev Cell Dev Biol 27:653-679. CrossRef Medline

Lehtinen MK, Zappaterra MW, Chen X, Yang YJ, Hill AD, Lun M, Maynard T, Gonzalez D, Kim S, Ye P, D’Ercole AJ, Wong ET, LaMantia AS, Walsh CA (2011) The cerebrospinal fluid provides a proliferative niche for neural progenitor cells. Neuron 69:893-905. CrossRef Medline

Louvi A, Grove EA (2011) Cilia in the CNS: the quiet organelle claims center stage. Neuron 69:1046-1060. CrossRef Medline

Mairet-Coello G, Tury A, DiCicco-Bloom E (2009) Insulin-like growth factor-1 promotes $\mathrm{G}(1) / \mathrm{S}$ cell cycle progression through bidirectional regulation of cyclins and cyclin-dependent kinase inhibitors via the phos- 
phatidylinositol 3-kinase/Akt pathway in developing rat cerebral cortex. J Neurosci 29:775-788. CrossRef Medline

Manno CS, Pierce GF, Arruda VR, Glader B, Ragni M, Rasko JJ, Ozelo MC, Hoots K, Blatt P, Konkle B, Dake M, Kaye R, Razavi M, Zajko A, Zehnder J, Rustagi PK, Nakai H, Chew A, Leonard D, Wright JF, et al. (2006) Successful transduction of liver in hemophilia by AAV-Factor IX and limitations imposed by the host immune response. Nat Med 12:342-347. CrossRef Medline

Manzini MC, Walsh CA (2011) What disorders of cortical development tell us about the cortex: one plus one does not always make two. Curr Opin Genet Dev 21:333-339. CrossRef Medline

Martín C, Bueno D, Alonso MI, Moro JA, Callejo S, Parada C, Martín P, Carnicero E, Gato A (2006) FGF2 plays a key role in embryonic cerebrospinal fluid trophic properties over chick embryo neuroepithelial stem cells. Dev Biol 297:402-416. CrossRef Medline

Mirzadeh Z, Merkle FT, Soriano-Navarro M, Garcia-Verdugo JM, AlvarezBuylla A (2008) Neural stem cells confer unique pinwheel architecture to the ventricular surface in neurogenic regions of the adult brain. Cell Stem Cell 3:265-278. CrossRef Medline

Neugebauer JM, Amack JD, Peterson AG, Bisgrove BW, Yost HJ (2009) FGF signalling during embryo development regulates cilia length in diverse epithelia. Nature 458:651-654. CrossRef Medline

Nielsen CM, Dymecki SM (2010) Sonic hedgehog is required for vascular outgrowth in the hindbrain choroid plexus. Dev Biol 340:430-437. CrossRef Medline

Parada C, Gato A, Bueno D (2005) Mammalian embryonic cerebrospinal fluid proteome has greater apolipoprotein and enzyme pattern complexity than the avian proteome. J Proteome Res 4:2420-2428. CrossRef Medline

Paulus W, Brandner S (2007) Choroid plexus tumors. In: WHO classification of tumours of the central nervous system (Louis DN, Ohgaki H, Wiestler OD, Cavenee WK, eds), pp 81-85. Lyon, France: IARC Press.

Perrin RJ, Fagan AM, Holtzman DM (2009) Multimodal techniques for diagnosis and prognosis of Alzheimer's disease. Nature 461:916-922. CrossRef Medline

Poduri A, Evrony GD, Cai X, Elhosary PC, Beroukhim R, Lehtinen MK, Hills LB, Heinzen EL, Hill A, Hill RS, Barry BJ, Bourgeois BF, Riviello JJ, Barkovich AJ, Black PM, Ligon KL, Walsh CA (2012) Somatic activation of AKT3 causes hemispheric developmental brain malformations. Neuron 74:41-48. CrossRef Medline

Potter R, Patterson BW, Elbert DL, Ovod V, Kasten T, Sigurdson W, Mawuenyega K, Blazey T, Goate A, Chott R, Yarasheski KE, Holtzman DM, Morris JC, Benzinger TL, Bateman RJ (2013) Increased in vivo amyloidbeta42 production, exchange, and loss in presenilin mutation carriers. Sci Transl Med 5:189ra177. CrossRef Medline

Redzic ZB, Preston JE, Duncan JA, Chodobski A, Szmydynger-Chodobska J (2005) The choroid plexus-cerebrospinal fluid system: from development to aging. Curr Top Dev Biol 71:1-52. CrossRef Medline

Safaee M, Oh MC, Bloch O, Sun MZ, Kaur G, Auguste KI, Tihan T, Parsa AT (2013) Choroid plexus papillomas: advances in molecular biology and understanding of tumorigenesis. Neuro Oncol 15:255-267. CrossRef Medline

Segal M (2005) Fluid compartments of the central nervous system. In:
The blood-cerebrospinal fluid barrier (Zheng W, Chodobski A, eds), pp 83-99. Boca Raton, FL: Taylor and Francis.

Serot JM, Béné MC, Foliguet B, Faure GC (2000) Monocyte-derived IL-10secreting dendritic cells in choroid plexus epithelium. J Neuroimmunol 105:115-119. CrossRef Medline

Shen Q, Wang Y, Kokovay E, Lin G, Chuang SM, Goderie SK, Roysam B, Temple S (2008) Adult SVZ stem cells lie in a vascular niche: a quantitative analysis of niche cell-cellinteractions. Cell Stem Cell 3:289-300. CrossRef Medline

Shook BA, Manz DH, Peters JJ, Kang S, Conover JC (2012) Spatiotemporal changes to the subventricular zone stem cell pool through aging. J Neurosci 32:6947-6956. CrossRef Medline

Tarawneh R, D’Angelo G, Macy E, Xiong C, Carter D, Cairns NJ, Fagan AM, Head D, Mintun MA, Ladenson JH, Lee JM, Morris JC, Holtzman DM (2011) Visinin-like protein-1: diagnostic and prognostic biomarker in Alzheimer disease. Ann Neurol 70:274-285. CrossRef Medline

Temple S, Alvarez-Buylla A (1999) Stem cells in the adult mammalian central nervous system. Curr Opin Neurobiol 9:135-141. CrossRef Medline

Thanos CG, Bintz B, Emerich DF (2010) Microencapsulated choroid plexus epithelial cell transplants for repair of the brain. Adv Exp Med Biol 670: 80-91. CrossRef Medline

Thomas T, Dziadek M (1993) Capacity to form choroid plexus-like cells in vitro is restricted to specific regions of the mouse neural ectoderm. Development 117:253-262. Medline

Thornton GK, Woods CG (2009) Primary microcephaly: do all roads lead to Rome? Trends Genet 25:501-510. CrossRef Medline

Tiberi L, Vanderhaeghen P, van den Ameele J (2012) Cortical neurogenesis and morphogens: diversity of cues, sources and functions. Curr Opin Cell Biol 24:269-276. CrossRef Medline

Toyoda R, Assimacopoulos S, Wilcoxon J, Taylor A, Feldman P, SuzukiHirano A, Shimogori T, Grove EA (2010) FGF8 acts as a classic diffusible morphogen to pattern the neocortex. Development 137:3439-3448. CrossRef Medline

Tropepe V, Craig CG, Morshead CM, van der Kooy D (1997) Transforming growth factor- $\alpha$ null and senescent mice show decreased neural progenitor cell proliferation in the forebrain subependyma. J Neurosci 17:7850 7859. Medline

Watanabe M, Kang YJ, Davies LM, Meghpara S, Lau K, Chung CY, Kathiriya J, Hadjantonakis AK, Monuki ES (2012) BMP4 sufficiency to induce choroid plexus epithelial fate from embryonic stem cell-derived neuroepithelial progenitors. J Neurosci 32:15934-15945. CrossRef Medline

Wolff JE, Sajedi M, Brant R, Coppes MJ, Egeler RM (2002) Choroid plexus tumours. Br J Cancer 87:1086-1091. CrossRef Medline

Yeh C, Li A, Chuang JZ, Saito M, Cáceres A, Sung CH (2013) IGF-1 activates a cilium-localized noncanonical G $\beta \gamma$ signaling pathway that regulates cell-cycle progression. Dev Cell 26:358-368. CrossRef Medline

Zappaterra MD, Lisgo SN, Lindsay S, Gygi SP, Walsh CA, Ballif BA (2007) A comparative proteomic analysis of human and rat embryonic cerebrospinal fluid. J Proteome Res 6:3537-3548. CrossRef Medline

Zappaterra MW, Lehtinen MK (2012) The cerebrospinal fluid: regulator of neurogenesis, behavior, and beyond. Cell Mol Life Sci 69:2863-2878. CrossRef Medline 